\title{
Movement of the bull shark (Carcharhinus leucas) in the upper Mississippi River Basin, North America
}

\author{
RYAN SHELL ${ }^{1, *}$ and NiCHOLAS GARDNER ${ }^{2}$ \\ ${ }^{1}$ Department of Vertebrate Paleontology, Cincinnati Museum Center, 1301 Western Ave, 45203 - Cincinnati, USA. ${ }^{2}$ Potomac State College, \\ West Virginia University, 101 Fort Avenue, 26726 - Keyser, USA. ORCID Ryan Shell (D) https://orcid.org/0000-0001-6634-3127, \\ Nicholas Gardner (D) https://orcid.org/0000-0002-5278-7541
}

Marine and Fishery Sciences MAFIS

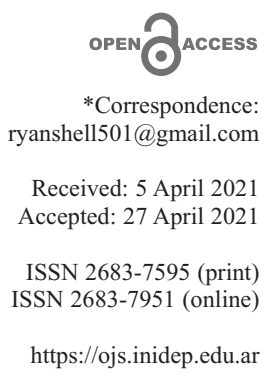

Journal of the Instituto Nacional de Investigación y Desarrollo Pesquero (INIDEP)

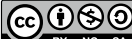

This work is licensed under a Creative Commons AttributionNonCommercial-ShareAlike 4.0 International License

\begin{abstract}
Rare appearances of bull sharks (Carcharhinus leucas) in river systems and other freshwater ecosystems have been reported from five continents. The wide geographic range of this phenomenon, the physiological adaptations of this species to allow for movement into rivers, and a fossil record in the Miocene Epoch, all imply that this behavior has a long history. In the Mississippi River basin, however, only two specimens were captured in the river's upper portion during the entire 20th century. Further historical, archeological, and paleontological records of these animals appearing farther than $500 \mathrm{~km}$ upstream from the Mississippi delta is almost nonexistent. Bull shark movements in the upper portions of this river are likely sufficiently rare or cryptic to avoid detection using historical, archaeological, paleontological, and modern fisheries conservation techniques. Deeper research into these sharks, and their historical biogeography is needed to better understand the relationship these large predators have to the freshwater ecosystems of the American mid-continent.
\end{abstract}

Key words: Bull shark, Carcharhinus leucas, biogeography, Illinois, Missouri, Mississippi River, cryptic species, zooarchaeology.

Movimiento del tiburón toro (Carcharhinus leucas) en la cuenca superior del Río Mississippi, América del Norte

RESUMEN. Se han reportado raras apariciones de tiburones toro (Carcharhinus leucas) en sistemas fluviales y otros ecosistemas de agua dulce en cinco continentes. El amplio rango geográfico de este fenómeno, las adaptaciones físiológicas de esta especie para permitir el movimiento hacia los ríos y un registro fósil en la época del Mioceno, implican que este comportamiento tiene una larga historia. En la cuenca del Río Mississippi, sin embargo, solo dos especímenes fueron capturados en la parte superior del río durante todo el siglo XX. Los registros históricos, arqueológicos y paleontológicos a más de $500 \mathrm{~km}$ río arriba del delta del Mississippi son casi inexistentes. Es probable que los movimientos del tiburón toro en las porciones superiores de este río sean lo suficientemente raros o crípticos como para evitar su detección utilizando técnicas históricas, arqueológicas, paleontológicas y modernas de conservación de la pesca. Se necesita una investigación más profunda sobre estos tiburones y su biogeografía histórica para comprender mejor la relación que estos grandes depredadores tienen con los ecosistemas de agua dulce del continente americano medio.

Palabras clave: Tiburón toro, Carcharhinus leucas, biogeografía, Illinois, Missouri, Río Mississippi, especies crípticas, zooarqueología. 
The bull shark, Carcharhinus leucas Müller and Henle, 1839, is an extant, large-bodied requiem shark that is well-known for its ability to move between freshwater and saltwater ecosystems (Ebert et al. 2013). The use of river systems by these apex predators sometimes extends $1,000 \mathrm{~km}$ or more from a river's mouth: Bull sharks have been recorded in the upper Amazon River of Peru, the upper Mississippi River Basin of the United States, and in other freshwater bodies such as the Zambezi and Ganges Rivers, of Africa and the Indian subcontinent, respectively (Gaussman 2018). Recent records of freshwater incursions have expanded to include the islands of Indonesia (Iqbal et al. 2019a, 2019b).

Bull shark fossil remains are known from the Miocene of North and South America (Cameron and Boreske 1972; Apolín et al. 2007), though fossil teeth similar to the 'bull [shark] group' of species may extend the North American record of similar animals to the Eocene (Cappetta 2012). Similarly, both the Mississippi and Amazon Rivers have geological histories spanning 10 million years or more. Given these observations, it is likely that far upstream exploration of river systems by these sharks is a behavior with a long history as well. However, it is not presently clear if the history of upstream exploration in the Mississippi River Basin is well-evidenced.

\section{MISSISSIPPI RIVER BULL SHARKS IN DEEP TO RECENT TIME}

In the Miocene and Pliocene North American fossil record, bull shark teeth are reported in marine depositional environments and marginal marine depositional environments, especially in North and South Carolina (Cameron and Boreske 1972). Their appearance in what were once marginal, near-shore ecosystems suggests a potential for past movement into fresh waters, but there are no definitive reports of bull shark teeth in MioPliocene freshwater deposits.

The Pleistocene to early Holocene record of freshwater bull sharks is equally limited. In the Pleistocene, remains from a possible estuarine deposit reported from Florida are known (Hulbert and Morgan 1989), but all similarly aged bull shark localities near the mouth of the Mississippi River are most certainly marine (Ebersole et al. 2017). Historic accounts of shark teeth from Pleistocene to Holocene Mississippi River gravels in western Illinois lack the identification of teeth to species level or sketches/photographs of the teeth that would aid current researchers in identifying the specimens (Worthen 1882).

The Holocene archaeological record of shark teeth found at inland Indigenous American sites is fairly rich, especially in the Ohio River Valley portion of the upper Mississippi River Basin. But here bull shark teeth occur alongside marine sharks such as the white shark (Carcharodon carcharias), or occur alongside the teeth of MiocenePliocene sharks, such as Hemipristus serra, Isurus (or Carcharodon) hastalis, or Carcharocles megalodon, suggesting their current context resulted from extra-regional trade or travel (Murphy 1975); which is well accepted for other exotics such as marine snail shells and alligator teeth (Colvin 2011).

One exception to the trend of non-contemporaneous shark tooth utilization by Indigenous peoples associated with the Mississippian material culture is the report of a non-fossil shark tooth from an archaeological site (Troyville and Coles Creek cultural stages) in Louisiana (Springer 1980). The tooth in question, however, was neither identified to the species level nor figured in sketches or photographs, and this record is from the lower Mississippi River Basin, so it does not shed light on the problem at hand.

Historic bull shark catches or sightings in the upper Mississippi River Basin seem absent prior to the 20th century, though confirmed catches of bull sharks occurred in Alton, Illinois in 1937 
(Thomerson et al. 1977) and St. Louis, Missouri near Rush Island Power Station in 1995 (Burr et al. 2004) (Figure 1).

Excluding the aforementioned accounts, the bull shark has not been confirmed to travel the Mississippi River Basin north of Louisiana, let alone the upper Mississippi River Basin. This is in spite of this species' capture in the Atchafalaya and Red Rivers. While archaeological records generally reveal an interest and use of shark teeth by Indigenous people during pre-Columbian time, there is no evidence this ever included the recovery of bull shark material from local fresh waters as opposed extra-regional trade (Murphy 1975; Colvin 2011). Finally, the North American fossil record also appears to lack confirmed alluvial deposits of bull shark remains in the Mississippi River Basin.

Given the fossil, archaeological, and historical rarity of bull sharks in the Mississippi River Basin of the United States, the historical behavior of this species to sometimes explore far upstream (with particular emphasis on occurrences near the city of St. Louis) in America's largest river basin may be described by one of three hypothetical explanations.
The first hypothesis would be that far upstream exploration, as a behavior, is very new and may have only begun in the last 1 million years or fewer. This appears unlikely (see below), but if it genuinely represents a true pattern, it could imply that the bull shark's ability to persist in freshwater may also be novel, in an evolutionary sense.

A second hypothesis is that the behavior is deeply rooted in the evolutionary history of this species. Given the wide global range of bull sharks that enter rivers, and their similarity to fresh water sharks of the Genus Glyphis this appears the most likely explanation (Fowler et al. 1997).

If either of these two hypotheses are true, it would indicate that bull sharks are capable of engaging in cryptic movement. This in turn seems to suggest that a group of these large bodied, aquatic apex-predators are capable of moving into the Mississippi River Basin and avoid being represented in the fossil record, the archaeological record, and (mostly) avoid detection by the modern society living along the waterways. Such cryptic movement appears to have extended past the placement of locks on the Mississippi River during the mid 20th century. The movement of these

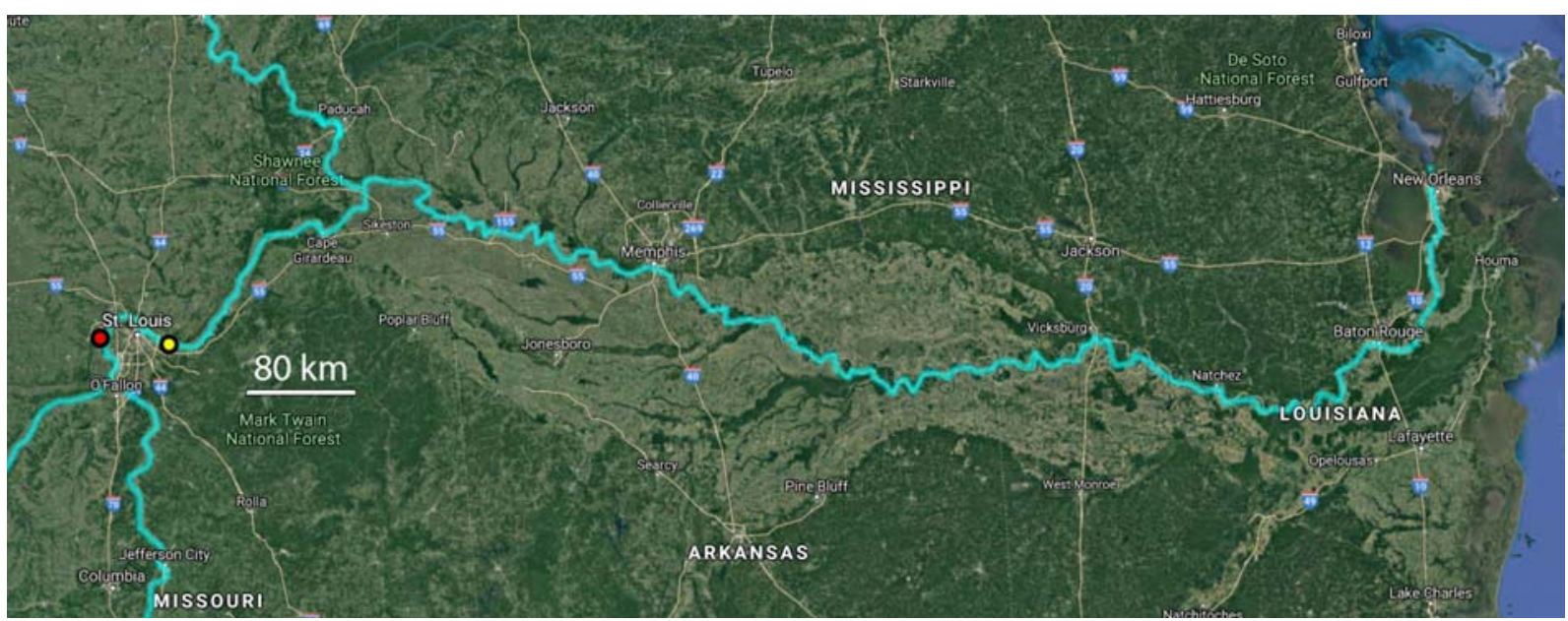

Figure 1. Map of historical records of bull sharks in the upper Mississippi River Basin. The Mississippi River is highlighted in light blue. Red dot: Alton, Illinois in 1937; yellow dot: Rush Island Power Station near St. Louis, Missouri in 1995. The base map was modified from Google Maps imagery derived from Landsat/Copernicus and TerraMetrics. 
sharks past locks begs a question on how many bull sharks enter the upper Mississippi River without detection to this day.

Finally, the third possible hypothesis is simply that the tendency of the bull shark to move into the upper Mississippi River is rare and anomalous to the point of being unprecedented in North America. It may be that the 1937 and 1995 captured specimens in Illinois and Missouri were hoaxes (despite photographic evidence for both) or totally dependent on random chance; that temperature differences between the Mississippi River and the Gulf of Mexico prevent bull sharks from exploring as far upstream as they do in the Amazon River. However, this does not seem particularly likely given that both 20th century records seem legitimate (see above), and that the average preferred temperature of this species is experienced or exceeded by the Mississippi River at Alton, Illinois over a large portion of the year (Elderkin and Klerks 2004; Kaschner et al. 2016).

Regardless of the reason for the paucity of data, in the absence of new confirmed catches, or new fossil and archaeological finds, the history of far-upstream exploration in the Mississippi River Basin by bull sharks remains in need of further research. Key areas for consideration should include to what extent physical barriers (such as locks) play a role in limiting bull shark upstream movement and what motivates or fails to motivate bull shark movement into upstream environments. How habitats, prey species, and species potentially competitive with bull sharks interact with this shark far upstream from the mouth of the Mississippi River will factor heavily into a more thorough understanding of these apparently cryptic predators.

\section{ACKNOWLEDGEMENTS}

We would like to express our thanks to colleagues who pre-read this report and offered use- ful suggestions during the final writing and editing phase, especially C. Bridges, M. Hintermeister, JP Hodnett, H. Robison, G. Storrs, and D. Cline. Additionally, we thank two anonymous reviewers whose comments helped strengthen this manuscript.

\section{REFERENCES}

Apolín J, González-Barba G, Martínez J. 2007. Seláceos del Mioceno superior de Quebrada Pajaritos (Piura, Perú). Sociedad Geológica del Perú, Publicación Especial. 6: 401-404.

Burr BM, Basile CM, AdAms GL, Nicholson MC. 2004. Exotic aquatic and terrestrial animals in the Hoosier-Shawnee ecological assessment area. In: THOMPSON FR, editor. The Hoosier-Shawnee Ecological Assessment. St. Johns (MI): U.S. Department of Agriculture, Forest Service, North Central Research Station. p. 236-267.

CAmeron B, Boreske JR. 1972. Clam borings in reworked whale skull, shark teeth and oysters: Miocene of Maryland and North Carolina. Geological Society of America. Abstracts. 4 (1): 7.

CAPPETTA H. 2012. Handbook of paleoichthyology. Vol. 3E. Chondrichthyes Mesozoic and Cenozoic Elasmobranchii: teeth. München: Verlag Dr. Freidrich Pfeil. 512 p.

Colvin GH. 2011. The presence, source and use of fossil shark teeth from Ohio archaeological sites. Ohio Archaeol. 61: 26-46.

Ebersole JA, Ebersole SM, Cicimurri DJ. 2017. The occurrence of early Pleistocene marine fish remains from the Gulf Coast of Mobile County, Alabama, USA. Palaeodiversity. 10: 97-115. doi:10.18476/pale.v10.a6

EBert DA, Fowler SL, Compagno LJV. 2013. Sharks of the world. Princeton (NJ): Princeton University Press. 
Elderkin CL, Klerks PL. 2004. Variation in thermal tolerance among three Mississippi River populations of the zebra mussel, Dreissena polymorpha. J Shellfish Res. 24: 221226. doi:10.2983/0730-8000(2005)24[221: VITTAT]2.0.CO;2

Fowler SL, REED TM, DipPer FA. 1997. Elasmobranch biodiversity, conservation, and management. Proceedings of the International Seminar and Workshop, Sabah, Malaysia, July 1997. Gland, Switzerland: The IUCN Species Survival Commission. https://portals.iucn.org/ library/efiles/documents/ssc-op-025.pdf.

Gaussman P. 2018. Synopsis of global freshwater occurrences of the bull shark (Carcharhinus leucas Valenciennes 1839, Carcharhinidae) with comments on the geographical range. ResearchGate. [2018 June]. https://www. researchgate.net/profile/Peter-Gausmann/ publication/325737350_Synopsis_of_global freshwater_occurrences_of the bull_shark_C archarhinus_leucas_VALENCIENNES_1839 _Carcharhinidae_with_comments_on_the_ge ographical_range/links $/ 5 \mathrm{~b} 20 \mathrm{f} 4 \mathrm{f} 44585 \overline{1} 5270 \mathrm{fc}$ $6379 \mathrm{~d} /$ Synopsis-of-global-freshwater-occur rences-of-the-bull-shark-Carcharhinus-leucasVALENCIENNES-1839-Carcharhinidaewith-comments-on-the-geographical-range.pdf.

Hulbert RC, GS Morgan. 1989. Stratigraphy, paleoecology, and vertebrate fauna of the Leisey Shell Pit local fauna, early Pleistocene (Irvingtonian) of southwestern Florida. Papers in Florida Paleontology. 2: 1-19.

Iqbal M, Nurnawati E, Setiawan A, Dahlan Z, YUSTIAN I. 2019a. First photographic inland records of bull shark Carcharinus leucas (Carchariniformes: Carcharinidae) in Sumatran waters, Indonesia. Ecol Montenegrina. 22: 171-176.

Iqbal M, Setiawan A, Yustian I. 2019b. First inland record of bull shark Carcharinus leucas (Carchariniformes: Carcharinidae) in Indonesian Borneo. Ecol Montenegrina. 22: 52-57.

Kaschner K, Kesner-Reyes K, Garilao C, Rius-Barile J, Rees T, Froese R. 2016. AquaMaps: predicted ranges for aquatic species. Version 08/2016. [accessed 2021 February]. https://www.aquamaps.org/.

MurPHY JL. 1975. Shark tooth caches in Wayne County, Ohio. Ohio Archaeol. 25: 26-27.

SPRINGER JW. 1980. An analysis of prehistoric food remains from the Bruly St. Martin Site, Louisiana, with a comparative discussion of Mississippi Valley faunal studies. MidCont J Archaeol. 5: 193-223.

Thomerson JE, Thorson TB, Hempel RL. 1977. The bull shark, Carcharhinus leucas, from the upper Mississippi River near Alton, Illinois. Copeia. 1977: 166-168. doi:10.2307/1443522

WORTHEN AH. 1882. Economical geology of Illinois. Springfield (IL): Illinois State Geological Survey. https://archive.org/details/ economicalgeolog02wort. 
